\title{
Shedding light on the diet of the Lessepsian yellowspotted puffer Torquigener flavimaculosus Hardy and Randall, 1983 in the Eastern Mediterranean
}

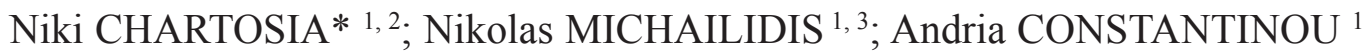 \\ and Paraskevi K. KARACHLE ${ }^{4}$ \\ ${ }^{1}$ Department of Biological Sciences, University of Cyprus, \\ 1 Panepistimiou Str., 2109 Aglantzia, Nicosia, Cyprus
}

${ }^{2}$ Oceanography Centre, University of Cyprus, P.O. Box 20537, 1678 Nicosia, Cyprus

${ }^{3}$ Department of Fisheries and Marine Research, 101 Vithleem Str., 1416 Strovolos, Nicosia, Cyprus.

${ }^{4}$ Institute of Marine Biological Resources and Inland Waters, Hellenic Centre for Marine
Research, $46.7 \mathrm{~km}$ Athens Sounio ave., P.O. Box 712, 19013 Anavyssos Attiki, Greece

*Corresponding author,e-mail: nchartos@ucy.ac.cy

The stomach contents of 104 individuals of Torquigener flavimaculosus from Cyprus were examined. The analysis revealed that it is an omnivorous species with a preference to animal prey, especially invertebrates with limited mobility (crustaceans, molluscs, echinoderms). The study of the length-weight relationship indicated a negative allometric growth for both sexes. It seems that its preference to consume invertebrates, its high toxicity due to high concentrations of tetrodotoxin in its tissues and some other biological characteristic reinforce its characterisation as invasive and monitoring actions should be designed for such species.

Key words: Lessepsian pufferfish; diet; Tetraodontidae; Cyprus

\section{INTRODUCTION}

Biological invasions are well acknowledged as one of the main threats to the marine environment, threatening biodiversity, and with major ecological and economic impacts (e.g., VILÀ et al., 2010). The Mediterranean Sea is susceptible to biological invasions, with the Suez Canal being the major pathway of introductions (e.g. ZENETOS et al., 2012), the latter being much more intense in the Levant than in the Western Mediterranean (ZENETOS et al., 2010, 2012; GALIL et al., 2017). Hence, it is of high priority to fill-in the knowledge gaps on the biology and ecology of the invasive species towards managing and mitigating their impacts (GOREN et al., 2016; DIMARCHOPOULOU et al., 2017).

Pufferfish (Tetraodontidae) are mainly distributed in tropical and subtropical areas of the Atlantic, Indian and Pacific Ocean and at least 
10 species have been reported in the eastern Mediterranean according to FARRAG et al. (2016) (Ephippion guttifer, Sphoeroides marmoratus, S. spengleri, S. pachygaster Tylerius spinosissimus, Lagocephalus guentheri, L. lagocephalus, L. sceleratus, L. suezensis and Torquigener flavimaculosus). In Cyprus, additionally to the native Sphoeroides pachygaster and Lagocephalus lagocephalus (FROESE \& PAULY, 2019), four alien pufferfish have been recorded: Lagocephalus guentheri, L. sceleratus, L. spadiceus is not considered because it was probably a misidentified L. guentheri - see MATSUURA et al. 2011, L. suezensis and Torquigener flavimaculosus (MARTINOU et al., 2018). The yellowspotted pufferfish Torquigener flavimaculosus Hardy and Randall, 1983 is a shallow water reef-associated species, distributed in the tropical and temperate regions of the Western Indian Ocean, the Persian Gulf and Seychelles (FROESE \& PAULY, 2019). In the Mediterranean, it was initially recorded as a Lessepsian migrant in Israel (GOLANI, 1987), and nowadays is widely distributed in the eastern part (e.g. Turkey: BILECENOĞLU, 2003; Greece: CORSINI-FOKA et al., 2006; Syria: SABOUR et al. 2014; Mediterranean Egypt: FARRAG et al., 2016; Libya: AL-MABRUK et al., 2018). In Cyprus, it was first recorded in 2009 (MICHAILIDIS, 2010) and today dense populations are found all around the coastal areas of Cyprus, listing it in the top six invasive species for the island (MARTINOU et al., 2018). Further, its commercial exploitation is forbidden (EC, 2004), as it contains tetrodotoxin - TTX and thus cannot be consumed by humans (KOSKER et al., 2018). Studies concerning its biology are rather limited (length-weight relationship: EDELIST (2014), ERGÜDEN et al. (2015), AYAS et al. (2019), BILGE et al. (2019); gonadal maturation and development: ÇEK-YALNIZ et al. (2017), RAMADAN \& ELHALFAWY (2019).

Here we try to fill-in the gap of knowledge regarding mainly the food preferences of $T$. flavimaculosus in Mediterranean waters, essential for evaluating the species' impacts on the coastal ecosystems and its role in the food webs of the oligotrophic Levantine, based on data collected from the waters of Cyprus.

\section{MATERIAL AND METHODS}

Samples were collected (January-August 2016) in three areas of the south coasts of the island (Paralimni, Liopetri, Cape Greco) by professional fishers (trammel nets: $36 \mathrm{~mm}$ inner panel mesh-size) at depths ranging from 15 to $50 \mathrm{~m}$, from soft bottom (sand - mud) habitats. Nets were set maximum 2 hours before sunrise and hauled-in up to one hour after sunrise. Individuals were transported immediately to the laboratory and were stored in the freezer $\left(-18^{\circ}\right.$ C). The total (TL) and standard (SL) lengths were measured to the nearest millimetre $(\mathrm{mm})$, and the total wet weight (TW) was recorded to the nearest gram $(\mathrm{g})$. Based on these measurements the TL-TW and TL-SL, relationships were established. Statistical differences from the $b$ isometric value of 3 (FROESE, 2006) (overall and between sexes) were tested by means of t-test. Following, each individual was dissected, sexed and the alimentary tract was removed for diet analysis. Gonads were removed and weighed (gonad weight - GW in $0.01 \mathrm{~g}$ ). Chisquare $\left(\chi^{2}\right)$ was used to identify significant differences between sexes.

The vacuity index (VI\%) was estimated, as the percentage of empty stomachs (VI\% = $(\mathrm{E} / \mathrm{T})^{*} 100$, where $\mathrm{E}$ is the number of empty stomachs and $\mathrm{T}$ is the number of stomachs examined). The overall stomach contents were then weighed to the nearest gram (g) and each item was identified to the lowest possible taxonomic level. Then every food item was counted, and the following indices were estimated:

Frequency of occurrence (F\%): $\mathrm{F}=\mathrm{n} * 100 /$ Ns

Percentage of prey $(\mathrm{N} \%)$ : $N=n^{\prime} * 100 / \mathrm{Np}$

where $\mathrm{n}=$ the number of stomachs containing a certain prey; $\mathrm{Ns}=$ the total number of stomachs examined; n' $=$ the total number of individuals of a certain prey; $\mathrm{Np}=$ the total number of prey items (HYSLOP, 1980; AMUNDSEN \& SÁNCHEZ-HERNÁNDEZ, 2019). Based on the N\% values, the fractional trophic level (TROPH) values were estimated using the routine for qualitative data of TrophLab (PAULY et al. 2000). 


\section{RESULTS AND DISCUSSION}

In total, 104 yellow spotted pufferfish individuals were examined, of which 84 were males and 20 females (sample sex ratio $=4: 1\left(\mathrm{x}^{2}=\right.$ $37.8, \mathrm{p}<0.0001)$. Total length (TL) and total weight (TW) ranges and mean values of both sexes were different with the females being slightly bigger $(\mathrm{TL}: \mathrm{t}=-3.58, \mathrm{df}=24, \mathrm{p}<0.01)$ and heavier than males (TW: $\mathrm{t}=-4.27, \mathrm{df}=21$, $\mathrm{p}<0.01$ ) (Table 1). RAMADAN \& ELHALFAWY (2019) recorded $1 \mathrm{M}: 1.08 \mathrm{~F}$ in populations from the Suez Canal. ÇEK- YALNIZ et al. (2017) reported $1 \mathrm{M}: 1.7 \mathrm{~F}$ in Iskenderun Bay, southeast coast of Turkey, a female biased ratio, based on a too low sample number ( 8 individuals) to statistically evaluate. Although these differences in sex ratios need further investigation and a higher number of individuals in order to be representative for the population of the species. they might be the result of gear selectivity, spatial segregation of sexes, or a feeding behaviour (RAMADAN \& ELHALFAWY 2019) or even of different depth distribution or habitat preferences between sexes. The length-weight relationship (LWR) indicated a negative allometric growth (the fish becomes slender with increasing length) for each sex separately and for both sexes combined $(b<3$; Fig. 1). The slopes of the equations of the sexes did not show any statistically significant difference $(p>0.05)$. Our results on LWR are in
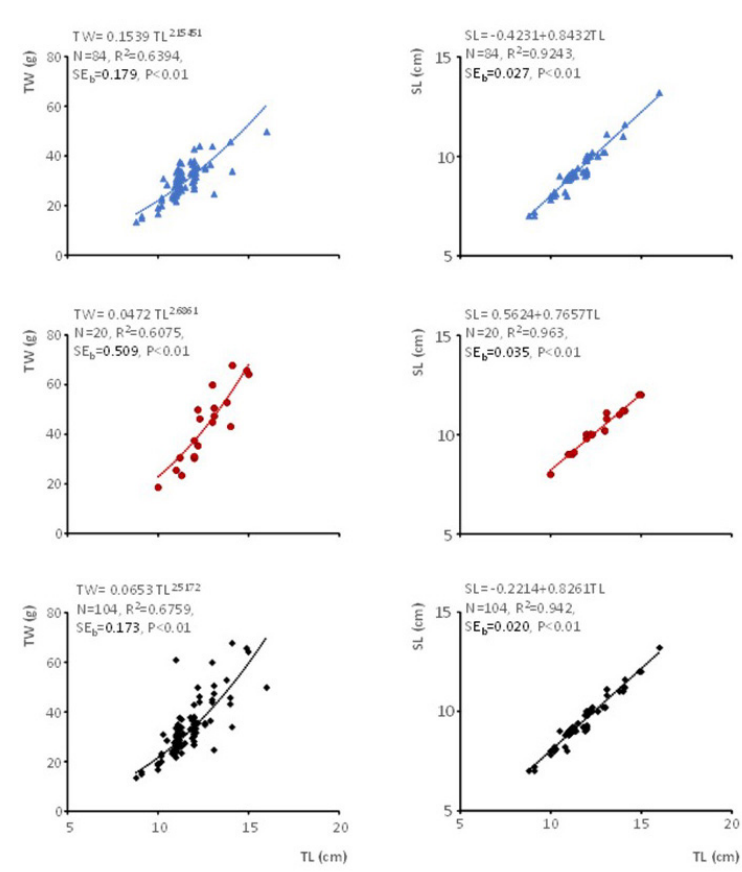

FIG. 1. Total length (TL) - total weight (TW) (left) and TL-standard length (SL) (right) relationships of Torquigener flavimaculosus per sex (males: top; females: middle) and combined (bottom), in Cyprus.

accordance with the findings from other Mediterranean areas (Israel: $b=2.22$ (EDELIST, 2014); Turkey: $b=2.902$ (ERGÜDEN et al., 2015), $b=2.84$ (BILGE et al., 2019). Only AYAS et al. (2019) showed positive allometry for fish from Mersin Turkey $(b=3.33)$.

For the determination of the feeding intensity, all examined individuals were classified accord-

Table 1. Total length, body weight, gonad weight and TROPH level of the examined samples of Torquigener flavimaculosus from Cyprus, per sex and in total

\begin{tabular}{|c|c|c|c|}
\hline & Combined & $\hat{\partial} \sigma^{\lambda}$ & 우우 \\
\hline$n$ & 104 & 84 & 20 \\
\hline $\mathrm{TL}-\mathrm{cm}($ mean $\pm \mathrm{SE})$ & $8.8-16.0(11.63 \pm 0.12)$ & $8.8-16.0(11.41 \pm 0.11)$ & $10.0-15.0(12.56 \pm 0.30)$ \\
\hline $\mathrm{TW}-\mathrm{g}($ mean $\pm \mathrm{SE})$ & $13.4-67.68(32.51 \pm 1.02)$ & $13.4-49.78(29.71 \pm 0.72)$ & $18.57-67.68(44.25 \pm 3.33)$ \\
\hline $\mathbf{G W}-\mathbf{g}($ mean $\pm \mathrm{SE})$ & $0.14-12.73(2.89 \pm 0.24)$ & $0.22-8.8(2.43 \pm 0.17)$ & $0.14-12.73(4.73 \pm 0.90)$ \\
\hline VI (\%) & 28.84 & 31.0 & 15.0 \\
\hline $\mathrm{TROPH} \pm \mathrm{SE}$ & $3.47 \pm 0.49$ & $3.47 \pm 0.49$ & $3.46 \pm 0.49$ \\
\hline
\end{tabular}

n, number of individuals; TL, total length; TW, Total weight; GW, Gonad Weight; VI, vacuity index; TROPH, trophic level; SE, standard error. 
ing to their stomach fullness. Out of 104 fish examined, $30(\mathrm{VI}=28.84 \%)$ had totally empty stomachs, while only 3 stomachs $(2.88 \%)$ were found full. The relationship between stomach and gonad weight showed that the months during gonad weight peak, the stomach was found to weigh less, meaning that it was less full or even empty. Therefore, it seems that there might be a lower feeding intensity during the spawning period, a common strategy in fish, because gonad size increase reduces the available space for stomach expansion; during this time, they probably rely mainly on their stored energy (e.g. HOFSTEDE et al., 2007). Another possible reason for the low percentage of full stomachs found, might be that this species perhaps is feeding during the day, thus until the time it was fished most of the prey was digested.

The analysis of the stomach contents of $T$. flavimaculosus showed that the fish is omnivorous with a preference in benthic crustaceans with reduced mobility, molluses and echinoderms (Table 2). The estimated TROPH values were similar between males and females with a value slightly lower than 3.5 (Table 1) classifying the species as an omnivore with preference to animals (sensu KARACHLE \& STERGIOU, 2017). GOREN et al. (2016) present a lower TROPH value for the species (3.2) a value obtained from FishBase. Yet, in the version of FishBase accessed in the current study (I.E. FROESE \& PAULY, 2019) the only TROPH value assigned for the species (i.e. $3.3 \pm 0.30$ ) is estimated based on "size and TROPHs of closest relatives". The stomach contents examination revealed 285 prey items in total, belonging to seven main prey categories (i.e., phyla and the category of eggs) (Table 2). The average prey item per individual was 2.71 $(\mathrm{SD}=4.58)$. The dominant prey category was Crustacea $(55.44 \% \mathrm{~N}, 75.68 \% \mathrm{~F})$, and the most abundant and frequent prey in Crustacea was Decapoda (all together) (34.04\% N, 31.08\% F). Anomura was the most abundant prey in Decapoda $(23.86 \%$ N, 22.97\% F). Mollusca $(12.63 \% \mathrm{~N}, 28.38 \% \mathrm{~F})$, and Echinodermata $(11.58 \%$ N, $31.08 \% \mathrm{~F})$ followed. Echinozoa $(6.32 \% \mathrm{~N}, 22.97 \% \mathrm{~F})$ was the most frequent prey in Echinodermata (Table 2). It seems that
T. flavimaculosus prefers eating benthic invertebrates and further investigation of the role of this fish on the benthic community structure is needed. Previous studies mention that predator fishes can have determinant role on the structure of the benthic invertebrate community (CHOAT, 1982). Additionally, as it was previously studied T. flavimaculosus exhibits a burrowing behaviour (BILECENOĞLU, 2005) and it was suggested that such a behaviour is an anti-predation adaptation. According to the prey preferences of T. flavimaculosus revealed from our study, it can be implied that such a burrowing behaviour could also be related to its feeding preferences and such a behaviour could facilitate the detection of its benthic prey.

The results of the present study show that the diet of T. flavimaculosus is quite different from the diet of other puffer fishes in the Mediterranean like Lagocephalus sceleratus (AYDIN, 2011; MICHAILIDIS, 2010; KALOGIROU et al., 2013) which is mainly an invertebrate (mainly cephalopods) and fish feeder. In T. flavimaculosus no cephalopods were found and the percentage of fish was low, while the percentages of crustacean and echinoderms were relatively high. It also worth noticing that the populations of Paracentrotus lividus in the waters north of Cyprus were observed to start declining in 2010 and collapsed in 2014 (ÇIÇEK, 2019). Lagocephalus sceleratus and T. flavimaculosus were initially suspected for this decline, but this hypothesis was not examined further, as $P$. lividus populations later collapsed in the whole Eastern Mediterranean and this was attributed to the rising seawater temperatures (ÇIÇEK, 2019 and references therein). According to our study, T. flavimaculosus consumes relative high quantities of Echinodermata and especially Echinozoa (including $P$. lividus), raising again the issue of its impacts on sea urchin populations, and thus indicating that the previous hypothesis should probably be reconsidered and further investigated.

T. flavimaculosus has been already classified as an invasive species (MARTINOU et al., 2018; www.cabi.org), of low vulnerability due to its low catchability to fisheries exploitation (FROESE \& PAULY, 2019) and the high concentrations of tetro- 
Table 2. Diet composition of Torquigener flavimaculosus from Cyprus

\begin{tabular}{|c|c|c|c|c|c|c|c|c|c|}
\hline \multirow{2}{*}{ Food item taxon } & \multicolumn{3}{|c|}{ Combined } & \multicolumn{3}{|c|}{ Males } & \multicolumn{3}{|c|}{ Females } \\
\hline & F\% & $\mathbf{N}$ & $\mathbf{N} \%$ & F\% & $\mathbf{N}$ & N\% & F\% & $\mathbf{N}$ & N\% \\
\hline Detritus & 18.92 & $*$ & $*$ & 16.22 & $*$ & $*$ & 2,70 & $*$ & $*$ \\
\hline PLANTAE & 9.46 & 7 & 2.46 & 8.11 & 6 & 2.52 & 1.35 & 1 & 2.13 \\
\hline ANNELIDA & 12.16 & 9 & 3.16 & 8.11 & 6 & 2.52 & 4.05 & 3 & 6.38 \\
\hline Polychaeta & 12.16 & 9 & 3.16 & 8.11 & 6 & 2.52 & 4.05 & 3 & 6.38 \\
\hline MOLLUSCA & 28.38 & 36 & 12.63 & 22.97 & 30 & 12.61 & 5.41 & 6 & 12.77 \\
\hline Gastropoda ni & 22.97 & 25 & 8.77 & 20.27 & 21 & 8.82 & 2.70 & 4 & 8.51 \\
\hline Bivalvia ni & 12.16 & 11 & 3.86 & 9.46 & 9 & 3.78 & 2.70 & 2 & 4.26 \\
\hline CRUSTACEA & 75.68 & 158 & 55.44 & 62.16 & 140 & $58.82-$ & 13.51 & 18 & 38.30 \\
\hline Copepoda & 1.35 & 2 & 0.70 & 1.35 & 2 & 0.84 & & & \\
\hline Isopoda & 18.92 & 21 & 7.37 & 17.57 & 20 & 7.02 & 1.35 & 1 & 2.13 \\
\hline Isopoda ni & 6.76 & 5 & 1.75 & 6.76 & 5 & 2.10 & & & \\
\hline Gnathia spp larva & 18.92 & 20 & 7.02 & 17.57 & 19 & 7.98 & 1.35 & 1 & 2.13 \\
\hline Decapoda & 31.08 & 97 & 34.04 & 24.32 & 84 & 35.29 & 6.76 & 13 & 27.66 \\
\hline Decapoda ni & 2.70 & 2 & 0.70 & 2.70 & 2 & 0.84 & & & \\
\hline \multicolumn{10}{|l|}{ Anomura } \\
\hline Paguroidea ni & 22.97 & 68 & 23.86 & 20.27 & 65 & 27.31 & 2.70 & 3 & 6.38 \\
\hline Anapagurus laevis & 1.35 & 3 & 1.05 & & & & 1.35 & 3 & 6.38 \\
\hline Anapagurus spp & 2.70 & 3 & 1.05 & 2.70 & 3 & 1.26 & & & \\
\hline Calcinus tubularis & 1.35 & 4 & 1.40 & & & & 1.35 & 4 & 8.51 \\
\hline Calcinus spp & 2.70 & 2 & 0.70 & & & & 2.70 & 2 & 4.26 \\
\hline Galathea spp & 1.35 & 3 & 1.05 & 1.35 & 3 & 1.26 & & & \\
\hline \multicolumn{10}{|l|}{ Brachyura } \\
\hline Brachyura ni & 1.35 & 1 & 0.35 & & & & 1.35 & 1 & 2.13 \\
\hline $\begin{array}{l}\text { Velolambrus } \\
\text { expansus }\end{array}$ & 1.35 & 1 & 0.35 & 1.35 & 1 & 0.42 & & & \\
\hline Brachyura larvae & 2.70 & 8 & 2.81 & 2.70 & 8 & 3.36 & & & \\
\hline Crustacea ni & 44.59 & 38 & 13.33 & 39.19 & 34 & 14.29 & 5.41 & 4 & 8.51 \\
\hline ECHINODERMATA & 31.08 & 30 & 11.58 & 28.38 & 28 & 12.61 & 2.70 & 3 & 6.38 \\
\hline Echinozoa & 22.97 & 18 & 6.32 & 21.62 & 17 & 7.14 & 1.35 & 1 & 2.13 \\
\hline Echinoidea ni & 14.86 & 11 & 3.86 & 14.86 & 11 & 4.62 & & & \\
\hline $\begin{array}{l}\text { Paracentrotus } \\
\text { lividus }\end{array}$ & 1.35 & 1 & 0.35 & 1.35 & 1 & 0.42 & & & \\
\hline Holothuroidea ni & 2.70 & 2 & 0.70 & 2.70 & 2 & 0.84 & & & \\
\hline Asterozoa & 2.70 & 3 & 1.05 & 1.35 & 2 & 0.84 & 1.35 & 1 & 2.13 \\
\hline Ophiuridea ni & 2.70 & 2 & 0.70 & 1.35 & 1 & 0.42 & 1.35 & 1 & 2.13 \\
\hline Ophiura spp & 1.35 & 1 & 0.35 & 1.35 & 1 & 0.42 & & & \\
\hline Echinodermata ni & 9.46 & 7 & 2.46 & 9.46 & 7 & 2.94 & & & \\
\hline PISCES & 5.41 & 4 & 1.40 & 5.41 & 4 & 1.68 & & & \\
\hline others (eggs) & 8.11 & 38 & 13.33 & 4.05 & 22 & 9.24 & 4.05 & 16 & 34.04 \\
\hline plastic debris & 17.57 & 16 & & 14.86 & 14 & & 2.70 & 2 & \\
\hline
\end{tabular}

$F$, frequency of occurrence of prey item; $N$, number of prey items; ni, not identified food item; VI, vacuity index. 
dotoxin in its tissues, capable to threaten human health (KOSKER et al., 2018). Our results together with those of the available literature, specifically the high diversity of benthic invertebrates in its diet, its small body size at maturity and its possibly extended maturity period, enhance its characterization as invasive (sensu ZENETOS et $a l ., 2005)$. As other marine invasive fish, they can have damaging consequences on biodiversity, ecosystems, fisheries, human health, tourism and coastal development and a close eye must be kept on their abundances. Thus, targeted monitoring actions are essential in order to keep their abundances as low as possible.

\section{CONCLUSIONS}

This study showed that T. flavimaculosus is an omnivorous species showing a preference in slow moving benthic invertebrates. Further, it seems that its diet is different from those of other puffer fishes studied from the Mediterranean, in terms of preferential prey. In contrast to the preference of other puffers towards cephalopods and fishes, T. flavimaculosus contained very little, if any, quantities of these food items. The observed decline of the populations of the sea urchin Paracentrotus lividus in the Eastern Mediterranean can probably be correlated with T. flavimaculosus since in the present study it has been found to prey upon the urchin. Yet, this hypothesis should be further explored in future studies.

\section{ACKNOWLEDGEMENTS}

The authors would like to thank the anonymous reviewers for their constructive comments which improved our manuscript. Further, the DFMR for providing part of the samples analysed in this research and Demetris Rovanias for his help in the laboratory work. This work was partly funded by the Research Project "PROTOMEDEA - Towards the establishment of Marine Protected Area Networks in the Eastern Mediterranean", supported by the Directorate-General for Maritime Affairs and Fisheries (DG MARE) of the European Commission, through the Grant Agreement SI2.721917.

\section{REFERENCES}

AL-MABRUK, S.A.A., V.O. STOILAS, P. KLEITOU \& I. GIOVOS. 2018. The first record of Torquigener flavimaculosus (Tetraodontiformes: Tetraodontidae) from Libya. J. Fish. Aquat. Stud., 6(4): 449-450.

AMUNDSEN, P.A. \& J. SÁNCHEZ-HERNÁNDEZ, 2019. Feeding studies take guts - critical review and recommendations of methods for stomach contents analysis in fish. J. Fish Biol., 95: 1364-1373.

AYAS, D., GÜRLEK, M., ÇIFTÇI, N., DOĞDU, S.A., AKBORA, H.D., MOEZ, S. \& TURAN, C. 2019. Length - weight relationships of pufferfish species (Tetraodontinae Bonaparte, 1832) from Mersin Bay, Northeastern Mediterranean Sea. In C. Turan and Y. Kutlu (Editors). Proceeding of Next Generation Biometry Workshop and Course. Sciences, Iskenderun, Turkey, 4 - 6 October 2019 Natural and Engineering, pp. 18-25.
AYDIN, M. 2011. Growth, reproduction and diet of pufferfish (Lagocephalus sceleratus Gmelin, 1789) from Turkey's Mediterranean Sea Coast. Turkish Journal of Fisheries and Aquatic Sciences, 11, 569-576.

BILECENOĞLU, M. 2003. Kızıldeniz göçmeni balon balığ̀ (Torquigener flavimaculosus Hardy and Randall, 1983), Türkiye kiyılarından ilk gözlemler. Sualtı Dünyası Dergisi, 74: 38-39.

BILECENOĞLU, M. 2005. Observation on the burrowing behaviour of the Dwarf Blaasop Torquigener flavimaculosus (Osteichthyes: Tetraodontidae) along the coast of Fethiye, Turkey. Zool. Middle East, 35: 29-34.

BILGE, G., H. FILIZ, S. YAPICI, A.S. TARKAN \& L. VILIZZI, 2019. A risk screening study on the potential invasiveness of Lessepsian fishes in the south-western coasts of Anatolia. Acta Ichthyol. Piscat., 49 (1): 23-31. 
ÇEK-YALNIZ, Ş., F. TURAN \& S.A. DOĞDU. 2017. Maturation and gonad development of Yellowspotted Puffer Torquigener flavimaculosus (Osteichthyes: Tetraodontidae) from Iskenderun Bay, North-eastern Mediterranean. NESciences, 2(3): 1-11.

CHOAT, J.H., 1982. Fish feeding and the structure of benthic communities in temperate waters. Annu. Rev. Ecol. Syst., 13: 423-449.

ÇIÇEK, B.A. 2019. Non-indigenous fish species in north of Cyprus: ecological status and impacts on key habitats. In: H. Langar and A. Ouerghi (Editors) UNEP/MAP - SPA/RAC, 2019. Proceedings of the 1st Mediterranean Symposium on the Non-Indigenous Species (Antalya, Turkey, 18 January 2019). SPA/ RAC publi., Tunis 2019. pp 40-44.

CORSINI-FOKA, M., P. MARGIES, G. KONDILATOS \& P. ECONOMIDIS, 2006. Torquigener flavimaculosus Hardy and Randall, 1983 (Pisces: Tetraodontidae) off Rhodes island marine area: a new alien fish in the Hellenic waters. Mediterr. Mar. Sci., 7(2): 73-76.

DIMARCHOPOULOU D., K.I. STERGIOU \& A.C. TSIKLIRAS. 2017. Gap analysis on the biology of Mediterranean marine fishes. PLoS One, 12: e0175949.

EDELIST, D. 2014. New length-weight relationshipships and Lmax values for fishes from the Southeastern Mediterranean Sea. J. Appl. Ichthyol., 30: 521-526.

ERGÜDEN, D., S.A. ERGÜDEN \& M. GÜRLEK. 2015. Length-weight relationships for six fish species in Iskenderun Bay (Eastern Mediterranean Sea coast of Turkey). J. Appl. Ichthyol., 31: 1148-1149.

FARRAG, M., A.A. EL-HAWEET, E.H.KH AKEL \& M.A. MOUSTAFA, 2016. Occurrence of puffer fishes (Tetraodontidae) in the eastern Mediterranean, Egyptian coast-filling in the gap. BioInvasions Rec., 5(1): 47-54.

FROESE, R. 2006. Cube law, condition factor and weight-length relationships: History, metaanalysis and recommendations. J. Appl. Ichthyol., 22: 241-253.

FROESE, R. \& D. PAULY. 2019. (Editors) FishBase. World Wide Web electronic publication, 2019. www.fishbase.org, version (08/2019) Accessed online 25 October 2019.
GALIL, B., A. MARCHINI, A. OCCHIPINTI- AMBROGI \& H. OJAVEER. 2017. The enlargement of the Suez Canal - Erythraean introductions and management challenges. Manag. Biol. Invasion 8: 47-54.

GOLANI, D. 1987. The Red Sea pufferfish, Torquigener flavimaculosus Hardy and Randall 1983. A new Suez Canal migrant to the eastern Mediterranean (Pisces; Tetraodontidae). Senckenb. marit., 19: 339-343.

GOREN, M., B.S. GALIL, A. DIAMANT \& N. STERN. 2016. Invading up the food web? Invasive fish in the southeastern Mediterranean Sea. Mar. Biol., 163, 180, https://doi.org/10.1007/ s00227-016-2950-7.

HOFSTEDE, R.T., M. DICKEY-COLLAS, I.T. MANTINGH \& A. WAGUE. 2007. The link between migration, the reproductive cycle and condition of Sardinella aurita off Mauritania, north-west Africa. Fish Biol., 71: 1293-1302.

HYSLOP, E.J. 1980. Stomach contents analysis - a review of methods and their application. Fish Biol., 17: 411-429.

KALOGIROU, S. 2013. Ecological characteristics of the invasive pufferfish Lagocephalus sceleratus (Gmelin, 1789) in the eastern Mediterranean Sea - a case study from Rhodes. Mediterr. Mar. Sci., 14: 251-260.

KARACHLE, P.K. \& K.I. STERGIOU. 2017. An update on the feeding habits of fish in the Mediterranean. Mediterr. Mar. Sci., 18(1): 141-152.

KOSKER, A.R., F. OZOGUL, M. DURMUŞ, Y. UÇAR, D. AYAS, V. SIMAT \& F. OZOGUL. 2018. First report on TTX levels of the yellowspotted pufferfish (Torquigener flavimaculosus) in the Mediterranean Sea. Toxicon, 148: 101-106.

MARTINOU, A., O. PESCOTT, N. MICHAILIDIS, A. ZENETOS, L. JENNA WONG \& S. PAGAD. 2018. Global Register of Introduced and Invasive Species - Cyprus. Invasive Species Specialist Group ISSG. Checklist dataset https://doi. org/10.15468/uryl57

MATSUURA, K., D. GOLANI \& S. BOGORODSKY. 2011. The first record of Lagocephalus guentheri Miranda Ribeiro, 1915 from the Red Sea with notes on previous records of $L$. lunaris (Actinopterygii, Tetraodontiformes, Tetraodontidae). Bull. Natl. Mus. Nat. Sci. Ser. A, 37: 163-169. 
MICHAILIDIS, N. 2010. Study on the Lessepsian migrant Lagocephalus sceleratus in Cyprus. EastMEd Technical Documents, pp 74-87.

PAULY, D., R. FROESE, P. SA-A, M.L. PALOMARES, V. CHRISTENSEN \& J. RIUS. 2000. Trophlab manual. ICLARM, Manila 3 pp.

RAMADAN, A.M. \& M.M. ELHALFAWY. 2019. Reproductive biology of the Yellow-spotted Puffer Torquigener flavimaculosus (Osteichthyes: Tetraodontidae) from Gulf of Suez, Egypt. EJABF 23(3), 503-511.

SABOUR, W., A. SAAD \& L. JAWAD. 2014. First record of the yellowspotted puffer Torquigener flavimaculosus Hardy and Randall, 1983 (Osteichthys: Tetraodontidae) from the Mediterranean Sea coasts of Syria, Thalassia Salent., 36(29): 29-34.

VILÀ, M., C. BASNOU, P. PYSEK, M. JOSEFSSON, P. GENOVESI, S. GOLLASCH, et al., 2010. How well do we understand the impacts of alien species on ecosystem services? A pan-European cross-taxa assessment. Front. Ecol. Environ. 8: 135-144.
ZENETOS, A., M. CINAR, M. PANCUCCI-PAPADOPOULOU, J. HARMELIN, G. FURNARI, F. ANDALORO, N. BELLOU, N. STREFTARIS \& H. ZIBROWIUS. 2005. Annotated list of marine alien species in the Mediterranean with records of the worst invasive species. Mediterr. Mar. Sci., 6(2): 63-118.

ZENETOS, A., S. GOFAS, M. VERLAQUE, M.E. ÇINAR, J.E. GARCIA RASO et al., 2010. Alien species in the Mediterranean Sea by 2010. A contribution to the application of European Union's Marine Strategy Framework Directive (MSFD). Part I. Spatial distribution. Mediterr. Mar. Sci., 11(2): 318-493.

ZENETOS, A., S. GOFAS, C. MORRI, A. ROSSO, D. VIOLANTI, et al. 2012. Alien species in the Mediterranean Sea by 2012. A contribution to the application of European Union's Marine Strategy Framework Directive (MSFD). Part 2. Introduction trends and pathways. Mediterr. Mar. Sci., 13(2): 328-352. 


\title{
Nova saznanja o prehrani lesepsijske žutopjegave četverozupke Torquigener flavimaculosus Hardy i Randall, 1983. u istočnom Sredozemlju
}

\author{
Niki CHARTOSIA*, Nikolas MICHAILIDIS, Andria CONSTANTINOU i \\ Paraskevi K. KARACHLE \\ *Kontakt, e-pošta: nchartos@ucy.ac.cy
}

\section{SAŽETAK}

Istraživan je sadržaj želudca 104 jedinke Torquigener flavimaculosus sa Cipra. Analizom je utvrđeno da se radi o svejedu u čijoj prehrani prevladava životinjski plijen, posebice beskralješnjaci ograničene pokretljivosti (rakovi, mekušci, bodljikaši). Istraživanje odnosa dužine i mase tijela pokazalo je negativan alometrijski rast za oba spola. Čini se da njegova sklonost konzumiranju beskralježnjaka, visoka toksičnost zbog visokih koncentracija tetrodotoksina u tkivima i neke druge biološke karakteristike pojačavaju njegovu karakterizaciju kao invazivne vrste, pa stoga za takve treba osmisliti mjere praćenja i kontrole.

Ključne riječi: lesepsijske četverozupke; prehrana; Tetraodontidae; Cipar 
